\title{
Lack of mutations in the leptin receptor gene in severely obese children
}

\author{
Ausência de mutação no gene receptor de \\ leptina em crianças gravemente obesas
}

\begin{abstract}
Natasha Favoretto Dias', Ariana Ester Fernandes', Maria Edna de Melo ${ }^{1,2,3}$, Heidi Lui Reinhardt' ${ }^{1}$, Cintia Cercato' ${ }^{3}$, Sandra Mara Ferreira Villares ${ }^{3}$, Alfredo Halpern ${ }^{3}$, Marcio C. Mancini ${ }^{1,2,3}$
\end{abstract}

\footnotetext{
${ }^{1}$ Liga de Obesidade Infantil, Disciplina de Endocrinologia e Metabologia, Hospital das Clínicas, Faculdade de Medicina, Universidade de São Paulo (HCFMUSP), São Paulo, SP, Brazil 2 Laboratório de Carboidratos e Radioimunoensaio/LIM-18, HCFMUSP, São Paulo, SP, Brazil ${ }^{3}$ Grupo de Obesidade e Síndrome Metabólica, Disciplina de Endocrinologia e Metabologia, HCFMUSP, São Paulo, SP, Brazil
}

Correspondence to: Ariana Ester Fernandes Av. Dr. Arnaldo, 455 01246-903 - São Paulo, SP, Brazil arianaefernandes@gmail.com

Received on 16/Mar/2011 Accepted on 15/Mar/2012

\section{ABSTRACT}

Objective: To analyze the LEPR gene in obese children and to investigate the associations between molecular findings and anthropometric and metabolic features. Subjects and methods: Thirty-two patients were evaluated regarding anthropometric characteristics, blood pressure, heart rate, serum glucose, insulin, leptin levels, and lipid profile. The molecular study consisted of the amplification and automatic sequencing of the coding region of LEPR in order to investigate new mutations. Results: We identified a high prevalence of metabolic disorders: impaired fasting glucose in $12.5 \%$ of the patients, elevated HOMA-IR in $85.7 \%$, low HDL-cholesterol levels in $46.9 \%$, high triglyceride levels in $40.6 \%$, and hypertension in $58.6 \%$ of the patients. The molecular study identified 6 already described allelic variants: rs1137100 (exon-2), rs1137101 (exon-4), rs1805134 (exon-7), rs8179183 (exon-12), rs1805096 (exon-18), and the deletion/insertion of the pentanucleotide CTTTA at 3'untranslated region. Conclusions: The frequency of alleles observed in this cohort is similar to that described in the literature, and was not correlated with any clinical feature. The molecular findings in the analysis of the LEPR did not seem to be implicated in the etiology of obesity in these patients. Arq Bras Endocrinol Metab. 2012;56(3):178-83

Keywords

Obesity; childhood obesity; leptin; leptin receptor gene

\section{RESUMO}

Objetivo: Analisar o LEPR em crianças obesas e investigar associações entre achados moleculares e características antropométricas e metabólicas. Sujeitos e métodos: Foram avaliados 32 pacientes quanto às características antropométricas, à pressão arterial, à frequência cardíaca, às dosagens séricas de glicemia, à insulina, à leptina e ao perfil lipídico. 0 estudo molecular consistiu na amplificação e no sequenciamento automático da região codificadora do LEPR para pesquisar mutações. Resultados: Identificou-se uma alta prevalência de distúrbios metabólicos: glicemia de jejum alterada em 12,5\%, HOMA-IR elevado em 85,7\%, níveis de HDL-colesterol baixos em $46,9 \%$, níveis de triglicérides elevados em $40,6 \%$ e hipertensão arterial em $58,6 \%$. O estudo molecular identificou 6 variações alélicas já descritas na literatura: rs 1137100 (éxon2), rs1137101 (éxon-4), rs1805134 (éxon-7), rs8179183 (éxon-12), rs1805096 (éxon-18) e deleção/ inserção do pentanucleotídeo CTTTA na região 3' não traduzida. Conclusões: A frequência das variações alélicas observada é semelhante à descrita na literatura e não se correlacionou com nenhuma característica clínica. Os resultados da análise molecular do LEPR não parecem estar implicados na etiologia da obesidade desses pacientes. Arq Bras Endocrinol Metab. 2012;56(3):178-83

\section{Descritores}

Obesidade; obesidade infantil; leptina; gene do receptor de leptina 


\section{INTRODUCTION}

$\mathrm{O}$ besity in childhood and adolescence is following the wide-reaching epidemic of obesity in adulthood. It is estimated that at least 155 million children worldwide are overweight or obese (1). The main factor responsible for the obesity epidemic seems to be the environmental change that promotes excessive calorie intake and physical inactivity in a population that had their genes selected for survival during times of privation (2).

Classically, few syndromes associated with obesity have been identified, in which mental retardation and abnormal development are also commonly observed (3). Besides these syndromes, in monogenic disorders, mutations have been described in patients in which obesity results from the loss of hypothalamic leptinmelanocortin pathway signaling, which is responsible for regulating satiety and energy expenditure (4-9).

Leptin is a hormone specifically produced by adipocytes, and its serum concentration is proportional to body fat mass which, in turn, has its amount regulated by the hypothalamic effects of leptin. Intravenous administration of leptin reduces appetite, while its deficiency increases food intake (10). Its action occurs by means of the leptin receptor, encoded by the LEPR gene. Which is located on the short arm of chromosome 1 , at position $1 \mathrm{p} 31$, and it is composed of 18 exons and 17 introns. It encodes a protein of 1,172 amino acids (816 amino acids in the extracellular domain, 303 in the intracellular domain, and 23 in the transmembrane domain), expressed mainly in the hypothalamus, and known as the OB-RL isoform (OB-large receptor). Three other minor isoforms are known, and the smallest one is OBRS (short OB-receptor), which is expressed in various tissues, such as the choroid plexus, lungs and kidneys (11).

LEPR mutations have been described in patients with early-onset severe obesity, although the prevalence of these mutations has not been systematically studied. Clément and cols. (6) documented the intronic mutation IVS16 + l G> A in LEPR, which causes early-onset severe obesity and pituitary dysfunction. Other mutations in LEPR have been described by Farooqi and cols. (12), in $3 \%$ of patients with severe obesity starting in childhood, and hyperphagic eating behavior. The sample in the study by Farooqi and cols. (12) showed BMI z scores of $5.1 \pm 1.6$ and body fat percentage of $52.8 \% \pm 3.2 \%$.

Thus, congenital LEPR deficiency should be considered in all patients with morbid obesity and hyperphagia in the absence of developmental delay and dys- morphic features, since this diagnosis may significantly alter the course of treatment, the choice of therapy, and allow genetic counseling for affected families.

Regarding polymorphisms in LEPR, Rosmond and cols. (13) identified the protective influence of two polymorphisms (Lys109Arg and Gln223Arg) against higher blood pressure levels. Men carrying arginine alleles had lower blood pressure levels; the difference was higher when subjects carried arginine in both codons. In the same group, hypertensive subjects had higher BMI, leptin levels, and frequency of Lys109 allele (14).

Moreover, polymorphisms in LEPR also seem to influence carbohydrate metabolism in women. Insulin response after an oral glucose load was significantly affected by Lys109Arg and Gln223Arg polymorphisms in post-menopausal women with impaired glucose tolerance. Insulin levels, adjusted for fat mass (fasting, $2 \mathrm{~h}$ and area under the curve of insulin) were about twofold higher in Lys109 and Gln223 homozygotes compared with Arg carriers (13).

Our goals in this study were to analyze the coding region of the leptin receptor gene in Brazilian children with early-onset severe obesity, and to investigate the associations between molecular findings and anthropometric and metabolic features.

\section{SUBJECTS AND METHODS}

Patients and parents or guardians received information about the research and signed a consent form. The inclusion criteria were: onset of obesity before the age of 4 years, inappropriately high leptin levels, and/or a BMI $\mathrm{Z}$ score $\geq 2.5$ according to the CDC growth charts (15) (this cutoff value was arbitrary). The exclusion criteria were: presence or suggestive features of genetic syndrome, obesity related to endocrine disease (Cushing's syndrome or hypothyroidism), and/or presence of chronic diseases, such as liver, kidney or heart failure.

\section{Clinical evaluation}

The sample consisted of 32 Brazilian patients with early-onset severe obesity (17 females, and 15 males) with mean age of $11 \pm 3.9$ years. Clinical evaluation included anthropometric measures (weight and height for BMI calculation), heart rate, and sitting blood pressure that was measured on the right arm after at least 5 minutes of rest. Systolic blood pressure (SBP) and diastolic blood pressure $(\mathrm{DBP})$ percentiles were calculated $(\mathrm{Na}-$ 
tional High Blood Pressure Education Program Working Group, 2004) (16). Laboratory tests performed with blood samples were: serum glucose, total cholesterol, HDL-cholesterol (HDL-c), LDL-cholesterol, triglyceride, aspartate aminotransferase (AST), alanine aminotransferase (ALT), gamma glutamyltransferase (GGT), thyroid stimulating hormone (TSH), free thyroxine (FT4), and leptin levels.

We adopted dyslipidemia cut-off values established by the First Brazilian Guideline for Atherosclerosis Prevention in Children and Adolescents, namely triglyceride levels $\geq 130 \mathrm{mg} / \mathrm{dL}$ and/or HDL-c $\leq 45 \mathrm{mg} /$ dL (17); and the American Diabetes Association criteria for diagnosis of impaired fasting glucose, namely glucose levels $>100 \mathrm{mg} / \mathrm{dL}$ (18). A homeostatic model assessment index (HOMA-IR) $>2.5$ was adopted as an index of insulin resistance (19).

\section{Molecular study}

Genomic DNA was extracted from peripheral blood leukocytes using the standardized protocols. DNA was amplified by PCR, using a set of primers to cover all exons and exon-intron boundaries regions of LEPR (Table 1). The samples were submitted to the following program for exon amplification: $94^{\circ} \mathrm{C}$ for 5 minutes, followed by 35 cycles of $94^{\circ} \mathrm{C}$ for 30 seconds; annea- ling temperature specific for each primer $\left(50-56^{\circ} \mathrm{C}\right)$ for 30 seconds; and $72^{\circ} \mathrm{C}$ for 30 seconds, followed by a final extension at $72^{\circ} \mathrm{C}$ for 10 minutes.

All reactions were carried out together with a negative control. Reading of the samples was carried out on agarose gel $2 \%$ with ethidium bromide $0.5 \mathrm{mg} / \mathrm{mL}$, and observed under ultraviolet transillumination.

All amplified products were purified using ExoSAP-IT (U.S. Biochemical, Cleveland, $\mathrm{OH}$ ) according to the manufacturer's instructions, and sequenced using a 3130 Analyzer (Applied Biosystems, Foster City, CA, USA). The sequence plots were compared with a normal sequence and database plots (ENSG00000116678).

\section{Statistics}

Clinical data of patients distributed as continuous variables are presented as means and standard deviations. Variables with nonparametric distribution are presented as medians and interquartile ranges. The association between specific allelic variant and metabolic disturbances (impaired fasting glucose, insulin resistance, hypertension, hypertriglyceridemia, and low HDL cholesterol) was assessed using the chi-square or Fisher's exact test. Statistical significance was set at $\mathrm{p}<0.05$. All statistical analyses were performed using SPSS software 16.0 (Statistical Package for Social Sciences Inc., USA).

Table 1. Sequence of primers, annealing temperature and amplicon size for PCR reactions

\begin{tabular}{|c|c|c|c|c|}
\hline Exon & Primer sense (5'-3') & Primer anti-sense (5'-3') & $\mathrm{T}\left({ }^{\circ} \mathrm{C}\right)$ & $\begin{array}{c}\text { Amplicon } \\
\text { (pb) }\end{array}$ \\
\hline 1 & CCTTTTCCAGGTGTACTTCT & CTCTACCATGTTTAAGGGC & 55 & 129 \\
\hline 2 & GAGCACTACATGGTTTAATC & AATCATAGCCATAAGACATC & 50 & 510 \\
\hline 3 & TTCACTGAGTTGTTCAGATGG & CTACTTCCGTATATGAAAGC & 52 & 175 \\
\hline 4 & ССТGCTTTAAAAGCCTATCC & GCCACTCTTAATACCCCCAG & 55 & 472 \\
\hline 5 & GTCCTTGGATAAAGTCACCT & TGCTATGGGACTTAAGAGGG & 55 & 349 \\
\hline 6 & CCACATCAACTTGATGTTCTG & CCAGTAGAAGTGGCTATTAC & 55 & 219 \\
\hline 7,8 & АTCTGATATCCTTTCTTCCC & TTITTATCTCACTGTGCCCA & 52 & 550 \\
\hline 9 & TCCCTGGTGCCAAAAGGTT & GACACAACGCAGCTTGACAT & 56 & 338 \\
\hline 10 & GCTTGATGAATACAGATGTATG & GAGGAAAGCTGAAGTTCTAAG & 56 & 277 \\
\hline 11,12 & GCCCTTTAGATACATATGTG & CAGGATTATGGACCATGAAG & 52 & 374 \\
\hline 13 & GCACTGCAGCCCTTAAACTA & GGATTACCACTCTGTACCTC & 56 & 287 \\
\hline 14 & GTCTTCTCTTCCTTATTCCC & AGGATGGTAGTATCCTCTAT & 52 & 406 \\
\hline 15 & GTATAAATGAGCCTITTACG & TTAGGCACACACATTGGTG & 50 & 178 \\
\hline 16 & CCTCAAGTTTCTGAGTTGTG & CGCGTAAGGACTTTTGCCGT & 54 & 153 \\
\hline 17 & GGCATAGTTGATCTGGTGGA & TGGCGTCTAGATTGCAATCG & 56 & 242 \\
\hline $18 \mathrm{~A}$ & CACACTTCCATTTCTGCCAGT & CAGCGTGGCGTATTTAACAA & 55 & 394 \\
\hline $18 \mathrm{~B}$ & TCTCTGAGGCTGAGGGTACTG & TCTCTCTCTTTTTGATTGAGGTGA & 55 & 420 \\
\hline $18 \mathrm{C}$ & TGGATGAACTTTTGAAATTGGA & CAAACAGACAACATTCATTTGGA & 55 & 633 \\
\hline
\end{tabular}




\section{RESULTS}

Clinical, biochemical and hormonal characteristics of patients are shown in table 2. In this group of children, we found a high prevalence of metabolic abnormalities. Impaired fasting glucose was present in $12.5 \%$ of the patients, elevated HOMA-IR in $85.7 \%$, low HDL-cholesterol in $46.9 \%$, high triglyceride levels in $40.6 \%$, and hypertension was present in $58.6 \%$ of patients.

No mutations or new polymorphisms were observed in the molecular analysis of this gene in $32 \mathrm{DNA}$ samples. Allelic variants previously described in a database were observed. SNPs were located in the 3' untranslated region (3'UTR), and in exons 2, 4, 7, 12 and 18 (Table 3). No association between allelic variant and metabolic disturbances were identified.

Table 2. Clinical, biochemical and hormonal characteristics of patients

\begin{tabular}{|c|c|}
\hline \multirow{2}{*}{ Parameter } & Mean \pm SD* $^{\star}$ \\
\hline & Median (Interquartile range) ${ }^{\star \star}$ \\
\hline Gender & 17F:15M \\
\hline Age (years) & $11.0 \pm 3.9^{*}$ \\
\hline Weight (kg) & $97.5 \pm 37.7^{\star}$ \\
\hline BMI $\left(\mathrm{kg} / \mathrm{m}^{2}\right)$ & $42.57 \pm 10.3^{\star}$ \\
\hline BMI Z-score & $+2.8(0.25)^{\star \star}$ \\
\hline SBP percentile & $79.1 \pm 28.6^{\star}$ \\
\hline DBP percentile & $85.4 \pm 16.7^{\star}$ \\
\hline Heart rate (bpm) & $87.7 \pm 13.7^{\star}$ \\
\hline Fasting glucose (mg/dL) & $85.8 \pm 14.1^{*}$ \\
\hline Fasting insulin (mUl/L) & $29.4 \pm 22.2^{*}$ \\
\hline Total cholesterol (mg/dL) & $157.6 \pm 35.3^{*}$ \\
\hline HDL cholesterol (mg/dL) & $40.1 \pm 8.4^{*}$ \\
\hline LDL cholesterol (mg/dL) & $91.1 \pm 25.8^{\star}$ \\
\hline Triglycerides (mg/dL) & $115.6 \pm 45.2^{\star}$ \\
\hline AST (UI/I) & $27.7 \pm 9.2^{*}$ \\
\hline ALT (U//I) & $32.6 \pm 19.7^{\star}$ \\
\hline TSH (mUl/l) & $2.9 \pm 1.2^{*}$ \\
\hline Free T4 (ng/dL) & $1.1 \pm 0.2^{*}$ \\
\hline Leptin (ng/mL) & $48.4(40.3)^{\star \star}$ \\
\hline
\end{tabular}

BMI: body mass index; SBP: systolic blood pressure; DBP: diastolic blood pressure; AST: aspartate aminotransferase; ALT: alanine aminotransferase; GGT: gamma glutamyltransferase; TSH: thyrotropin stimulating hormone; T4: thyroxine.

\section{DISCUSSION}

The findings reported here show high prevalence of metabolic disorders such as insulin resistance, dyslipidemia and hypertension related to severe obesity in a small sample of severely obese Brazilian children and adolescents.
Table 3. Frequency of allelic variations found in patients

\begin{tabular}{|c|c|c|c|}
\hline SNP & Exon & Replacement & Frequency \\
\hline \multirow[t]{2}{*}{ rs 1137100} & 2 & $\mathrm{~A} \mathbf{A} G>A \mathbf{G G}$ & A $81 \%$ \\
\hline & & K109R & G 19\% \\
\hline \multirow[t]{2}{*}{ rs1137101 } & 4 & $\mathrm{CAG}>\mathrm{CG} \mathrm{G}$ & A 68\% \\
\hline & & Q223R & G 32\% \\
\hline \multirow[t]{2}{*}{ rs1805134 } & 7 & $A G \mathbf{T}>A G \mathbf{C}$ & T 14\% \\
\hline & & S343S & C 86\% \\
\hline \multirow[t]{2}{*}{ rs8179183 } & 12 & $A A G>A A C$ & G 25\% \\
\hline & & K656N & C 75\% \\
\hline \multirow[t]{2}{*}{ rs1805096 } & 18 & $\mathrm{CCA}>\mathrm{CCG}$ & A $62 \%$ \\
\hline & & P1019P & G 38\% \\
\hline \multirow[t]{2}{*}{ Del/Ins* 3'UTR } & & & $-74 \%$ \\
\hline & & -/CTTTA & $26 \%$ \\
\hline
\end{tabular}

${ }^{*}$-: deletion; +: insertion.

\section{Clinical features}

Fasting glucose levels were elevated in $12.5 \%$ of the subjects, and HOMA-IR was increased in $85.7 \%$ of them. This information is in agreement with several studies, including a recent one by Pastucha and cols. (20) that demonstrated the validity of using the HOMA index for children and adolescents, and reported HOMA-IR of $4.58 \pm 1.92$ for obese children (BMI > p95), compared with $1.8 \pm 1.36$ for non-obese children, suggesting greater insulin resistance in obese children and adolescents. Another study conducted with 122 adolescents (21) also found that the obese group was more insulinresistant compared with the non-obese group.

Systemic hypertension, a multifactorial disease, was found in $58.6 \%$ of patients in our study. Considerable evidence indicates that hypertension is more common in obese children and adolescents. Recently, a Spanish study reported hypertension in $25 \%$ of cases, in a group of children and adolescents with a mean age similar to our cohort (respectively, $11.3 \pm 2.8$ and $11.0 \pm 3.9$ ) . However, mean BMI of our population was $42.57 \pm$ $10.3 \mathrm{~kg} / \mathrm{m}^{2}$, while the average BMI of the Spanish cohort $(22)$ was $27.9 \pm 3.6 \mathrm{~kg} / \mathrm{m}^{2}$.

Besides the influence of adiposity on blood pressure $(23,24)$ the Bogalusa Heart Study $(25)$ consolidated the relationship between blood pressure and insulin levels, even after adjusting it for BMI. Mean insulin levels in individuals of our study were $29.4 \pm 22.2 \mathrm{mIU} / \mathrm{L}$, while in the Spanish sample they were $12 \pm 6 \mathrm{mIU} / \mathrm{L}$.

The association between obesity and dyslipidemia was found in numerous studies. The Bogalusa Heart Study (25) found that overweight and obese students were 2.4 to 7.1 times more likely to have hypercholesterolemia, with elevated levels of LDL-cholesterol and 
triglycerides, and the relationship between hyperinsulinemia and dyslipidemia was also demonstrated (21).

Our series showed low HDL-cholesterol levels (mean levels, $40.1 \pm 8.4 \mathrm{mg} / \mathrm{dL}$ ) in $46.9 \%$ of cases, and elevated triglycerides (mean levels, $115.6 \pm 45.2$ $\mathrm{mg} / \mathrm{dL}$ ) in $40.6 \%$ of them. A Japanese cohort of 319 overweight children aged 6 to 12 years, found HDLcholesterol levels of $57 \pm 12 \mathrm{mg} / \mathrm{dL}$ for boys, and 55 \pm 11 for girls, and mean triglycerides of 107 (95\% CI 99 - 115) for boys, and 112 (95\% CI 100-125) for girls. However, both mean BMI $\left(24.8 \pm 2.1 \mathrm{~kg} / \mathrm{m}^{2}\right.$ in boys and $24.7 \pm 2.6 \mathrm{~kg} / \mathrm{m}^{2}$ in girls) and mean serum insulin levels (12.6 mIU/L in boys and $16.6 \mathrm{mIU} / \mathrm{L}$ in girls) were lower in Japanese children when compared to our cohort (26). Another population studied (290 children, mean age $11.3 \pm 2.8$ years, BMI $27.9 \pm 3,6$ $\mathrm{kg} / \mathrm{m}^{2}$ and insulin levels $\left.12 \pm 6 \mathrm{mUI} / \mathrm{L}\right)$ also showed better HDL-cholesterol $(47 \pm 11 \mathrm{mg} / \mathrm{dL})$ and triglyceride $(80 \pm 44 \mathrm{mg} / \mathrm{dL})$ levels than our group $(22)$.

Diseases associated to obesity are common in childhood patients. In our cohort, these morbidities were more severe probably because of the higher degree of adiposity.

\section{Molecular features}

Yiannakouris and cols. (27) showed that the rs1137101 polymorphism is more prevalent in obese than in non-obese patients $(20.7 \%$ versus $4.5 \%)$, and that it is a predictor of obesity and body composition. This finding was also observed in several studies, by Mattevi and cols. (28) and Duarte and cols. (29), carried out in Brazil; by Furusawa and cols. $(30,31)$, in two studies conducted in Japan; and in another study by Duarte and cols. (32), in which they described that this polymorphism increased the risk of obesity by $58 \%$. Chiu and cols. (33) also showed that the rs 1137101 polymorphism is associated with increased serum LDL-cholesterol levels, and higher rates of insulin resistance. However, a study conducted in Turkey with a group of 232 obese patients found no relationship between this polymorphism and BMI (34).

Among the studies conducted with children, Riestra and cols. (35) showed that the rs1137101 polymorphism is associated with higher serum leptin levels and BMI in girls, but this finding was not seen in boys. A Mexican study (36) conducted with 103 adolescents ( 55 obese and 48 non-obese) found that the rs1137101 polymorphism was more prevalent among individuals with higher levels of insulin, who also had a higher percentage of fat in body composition and higher serum leptin levels. Okada and cols. (37) who studied 136 obese children between 5 and 17 years found no relationship between this polymorphism and serum lipids.

The rs 1137100 polymorphism was not related to BMI, risk of obesity and body composition in several studies in the literature $(27,30,31)$. The rs 81789183 polymorphism was not associated with BMI and obesity (27) nor to insulin resistance (38). However, a Spanish study (39) carried out with 67 obese patients showed that the rs81789183 polymorphism was associated with decreased response to leptin, and lower weight loss secondary to changes in lifestyle behavior (hypocaloric diet and exercise). Among the studies involving children and adolescents, the results are also controversial, since Riestra and cols. (35) found no relationship between and rs81789183 and BMI or obesity, while Okada and cols. (37) associated the rs 1137100 polymorphism with higher serum lipid levels.

In our study, the prevalence of polymorphisms was similar to that described in the literature in obese patients. However, no causal relationship between these polymorphisms and metabolic disturbances (impaired fasting glucose, insulin resistance, hypertension, hypertriglyceridemia, hepatic transaminases, and low HDLcholesterol) was identified.

We did not find mutations in $L E P R$, confirming that these mutations are extremely rare causes of obesity. However, with the methodology we used, we cannot rule out modifications in the promoter region or in some transcription factor or post-translational defects that could lead to changes in the receptor.

In conclusion, LEPR point mutations are rare causes of obesity, even in individuals with early-onset and severe disease. The frequency of SNPs rs 1137100 , rs1137101, rs1805134, rs8179183, rs1805096, and deletion or insertion in the 3'UTR pentanucleotide CTTTA in our cohort was similar to that already described, and these mutations, isolated or in association, did not correlate with metabolic abnormalities. However, we found that the frequency of metabolic abnormalities increased with the degree of fatness.

Disclosure: no potential conflict of interest relevant to this article was reported.

\section{REFERENCES}

1. Haslam DW, James WP. Obesity. Lancet. 2005;366:1197-209.

2. Eaton SB, Konner M, Shotak M. Stone agers in the fast lane: chronic degenerative diseases in evolutionary perspective. Am J Med. 1988;84:739-49. 
3. FarooqilS, O'Rahilly S. Monogenic obesity in humans. Annu Rev Med. 2005;56:443-58.

4. Montague CT, Farooqi IS, Whitehead JP, Soos MA, Rau H, Wareham NJ, et al. Congenital leptin deficiency is associated with severe early-onset obesity in humans. Nature. 1997;387:903-8.

5. Strobel A, Issad T, Camoin L, Ozata M, Strosberg AD. A leptin missense mutation associated with hypogonadism and morbid obesity. Nat Genet. 1998;18:213-5.

6. Clément K, Vaisse C, Lahlou N, Cabrol S, Pelloux V, Cassuto D, et al. A mutation in the human leptin receptor gene causes obesity and pituitary dysfunction. Nature. 1998;392:398-401.

7. Krude H, Biebermann H, Luck W, Horn R, Brabant G, Gruters A. Severe early-onset obesity, adrenal insufficiency and red hair pigmentation caused by POMC mutations in humans. Nat Genet. 1998;19:155-7.

8. Jackson RS, Creemers JW, Ohagi S, Raffin-Sanson ML, Sanders L, Montague $\mathrm{CT}$, et al. Obesity and impaired prohormone processing associated with mutations in the human prohormone convertase 1 gene. Nat Genet. 1997;16:303-6.

9. Farooqi IS, Keogh JM, Yeo GS, Lank EJ, Cheetham T, O'Rahilly S. Clinical spectrum of obesity and mutations in the melanocortin 4 receptor gene. N Engl J Med. 2003;348:1085-95.

10. Zhang Y, Proenca R, Maffei M, Barone M, Leopold L, Friedman JM. Positional cloning of the mouse obese gene and its human homologue. Nature. 1994;372:425-32.

11. Chung WK, Power-Kehoe L, Chua M, Leibel RL. Mapping of the $O B$ receptor to $1 p$ in a region of nonconserved gene order from mouse and rat to human. Genome Res. 1996;6:431-8.

12. Farooqi IS, Wangensteen T, Collins S, Kimber W, Matarese G, Keogh JM, et al. Clinical and molecular genetic spectrum of congenital deficiency of the leptin receptor. New Engl $\mathrm{J}$ Med. 2007;356:237-47.

13. Rosmond R, Chagnon YC, Holm G, Chagnon M, Perusse L, Lindell $\mathrm{K}$, et al. Hypertension in obesity and the leptin receptor gene locus. J Clin Endocr Metab. 2000;85:3126-31.

14. Wauters M, Mertens I, Rankinen T, Chagnon M, Bouchard C, Van Gaal L. Leptin receptor gene polymorphisms are associated with insulin in obese women with impaired glucose tolerance. J Clin Endocr Metab. 2001;86:3227-32.

15. Cole TJ. The LMS method for constructing normalized growth standards. Eur J Clin Nutr. 1990;44(1):45-60.

16. National High Blood Pressure Education ProgramWorking Group on High Blood Pressure in Children and Adolescents. The Fourth Report on the Diagnosis, Evaluation, and Treatment of High Blood Pressure in Children and Adolescents. Pediatrics. 2004;114(2):555-76.

17. Sociedade Brasileira de Cardiologia. I Diretriz Brasileira sobre Prevenção de Aterosclerose em Crianças e Adolescentes. Arq Bras Cardiol. 2005;85(6):4-36.

18. American Diabetes Association. Standards of Medical Care in Diabetes. Diabetes Care. 2009;32(1):S13-61.

19. Matthews DR, Hosker JP, Rudenski AS, Naylor BA, Treacher DF, Turner RC. Homeostasis model assessment: insulin resistance and beta-cell function from fasting plasma glucose and insulin concentrations in man. Diabetologia. 1985;28:412-9.

20. Pastucha D, Talafa V, Malincikova J, Cihalik C, Hyjanek J, Horakova $D$, et al. Obesity, hypertension and insulin resistance in childhood - a pilot study. Biomed Pap Med Fac Univ Palacky Olomouc Czech Repub. 2010;154(1):77-82.

21. Steinberger J, Moorehead C, Katch V, Rocchini AP. Relationship between insulin resistance and abnormal lipid profile in obese adolescents. J Pediatr. 1995;126(5 Pt 1):690-5.

22. López-Capapé M, López-Bermejo A, Blanco M, Orejas E, Blasco J, Castellanos R. Esteatosis hepática, resistência al ainsulina y adiponectina en uma población com obesidad. An Pediatr (Barc). 2009;71(6):495-501.
23. Ward R. Familial aggregation and genetic epidemiology of blood pressure. In: Laragh JH, Brenner BM, eds. Hypertension: pathophysiology, diagnosis, and management. New York: Raven Press; 1990. p. 81-100.

24. Steiberger J, Daniels S. Obesity, insulin resistance, diabetes, and cardiovascular risk in children: an American Heart Association scientific statement from the atherosclerosis, hypertension, and obesity in the young committee (council on cardiovascular disease in the young) and the diabetes committee (council on nutrition, physical activity, and metabolism). Circulation. 2003;107;1448-53.

25. Jiang $X$, Srinivasan SR, Bao W, Berenson GS. Association of fasting insulin with blood pressure in young individuals. The Bogalusa Heart Study. Arch Intern Med. 1993;153:323-8.

26. Yoshinaga M, Sameshima K, TanakaY, Arata M, Wada A, Takahahsi H. Association between the number of cardiovascular risk factors and each risk factor level in elementary school children. Circ J. 2008;72:1594-7.

27. Yiannakouris N, Yannakoulia M, Melistas L, Chan JL, Klimis-Zacas D, Mantzoros CS. The Q223R polymorphism of the leptin receptor gene is significantly associated with obesity and predicts a small percentage of body weight and body composition variability. J Clin Endocrinol Metab. 2001;86(9):4434-9.

28. Mattevi VS, Zembrzuski VM, Hutz MH. Association analysis of genes involved in the leptin-signaling pathway with obesity in Brazil. Int J Obes Relat Metab Disord. 2002;26(9):1179-85.

29. Duarte SF, Francischetti EA, Genelhu-Abreu V, Barroso SG, Braga $\mathrm{JU}$, Cabello $\mathrm{PH}$, et al. p.Q223R leptin receptor polymorphism associated with obesity in Brazilian multiethnic subjects. Am J Hum Biol. 2006;18(4):448-53.

30. Furusawa T, Naka I, Yamauchi T, Natsuhara K, Kimura R, Nakazawa $M$, et al. The Q223R polymorphism in LEPR is associated with obesity in Pacific Islanders. Hum Genet. 2010;127(3):287-94.

31. Furusawa T, Naka I, Yamauchi T, Natsuhara K, Kimura R, Nakazawa $\mathrm{M}$, et al. The Q223R polymorphism in LEPR is associated with obesity in Pacific Islanders. Hum Genet. 2010;127(3):287-94.

32. Duarte SF, Francischetti EA, Genelhu VA, Cabello PH, Pimentel MM. LEPR p.0223R, beta3-AR p.W64R and LEP c.-2548G>A gene variants in obese Brazilian subjects. Genet Mol Res. 2007;6(4):1035-43.

33. Chiu KC, Chu A, Chuang LM, Saad MF. Association of leptin receptor polymorphism with insulin resistance. Eur J Endocrinol. 2004;150(5):725-9.

34. Mergen H, Karaaslan C, Mergen M, Deniz Ozsoy E, Ozata M. LEPR, ADBR3, RS-1 and 5-HTT genes polymorphisms do not associate with obesity. Endocr J. 2007;54(1):89-94.

35. Riestra P, García-Anguita A, Schoppen S, López-Simón L, de Oya M, Garcés C. Sex-specific association between leptin receptor polymorphisms and leptin levels and BMI in healthy adolescents. Acta Paediatr. 2010;99(10):1527-30.

36. Guízar-Mendoza JM, Amador-Licona N, Flores-Martínez SE, López-Cardona MG, Ahuatzin-Trémary R, Sánchez-Corona J. Association analysis of the GIn223Arg polymorphism in the human leptin receptor gene, and traits related to obesity in Mexican adolescents. J Hum Hypertens. 2005;19(5):341-6.

37. Okada T, Ohzeki T, Nakagawa Y, Sugihara S, Arisaka O; The Study Group of Pediatric Obesity and Its related metabolism. Impact of leptin and leptin-receptor gene polymorphisms on serum lipids in Japanese obese children. Acta Paediatr. 2010;99(8):1213-7.

38. Luis DA, Sagrado MG, Aller R, Izaola O, Conde R. Influence of Lys656Asn polymorphism of the leptin receptor gene on insulin resistance in nondiabetic obese patients. J Diabetes Complications. 2008;22(3):199-204.

39. Roman DL, Fuente RA, Sagrado MG, Izaola O, Vicente RC. Leptin receptor Lys656Asn polymorphism is associated with decreased leptin response and weight loss secondary to a lifestyle modification in obese patients. Arch Med Res. 2006;37(7):854-9. 